12. Стуканов В. Л. Уникальные свойства эфирних масел / В. Л. Стуканов // Лікув. прак. журн. - 2001. № 1-2 (12). - C 42-44.

13. Bielski J. Metodyka wychowania fizycznego i zdrowotnego / J. Bielski. - Kraków, 2005. - 361 c.

14. Nekhanevich O. B. The features of the morphologic and functional state of a main group of schoolboys with low physical health : Morphologia / O. B. Nekhanevich, S. V. Krasnozhon. - 2013. - 7(4). - P. 51-7.

Швайко Светлана, Дмитроца Елена, Стукало Окана, Шварц Людмила. Функциональное состояние респираторной системы младших школьнков под влиянием аромотерапии. Изучены особенности влияния длительной ароматерапии на функциональное состояние респираторной системы учеников младшего школьного возраста. В итоге исследования установлено, что основные антропометрические показатели исследуемых соответствуют возрастным нормам; отклонения от возрастных норм в большей мере касались массы тела и показателей роста в сторону снижения. Длительная аромотерапия влияет на снижение ЧСС исследуемых, улучшает ЖЕЛ. Частота дыхания, пробы с задержкой дыхания, ЖИ соответствуют возрастным нормам у всех исследуемых учеников.

Ключевые слова: респираторная система, функциональное состояние, соматометрия, младший школьный возраст, аромотерапия.

Shvayko Svitlana, Dmytrotsa Olena, Stykalo Oksana, Shvarcz Ludmyla. The Functional Condition of Respiratory System in Primary School Children Under the Influence of Aromatherapy. It was studied influence of lengthy aromatherapy on the functional condition of respiratory system in primary school children. It was found that the basic anthropometric indicators in the patients were normal, but it was found reduction in body weight and height in this patients. The lengthy aromatherapy is effecting on lowering heart rate and improving lung capacity in patients. The respiratory rate, the tests of breath holding and the vital index were normal in all children of primary school.

Key words: the respiratory system, the functional condition, the somatometry, the age of primary school, the aromatherapy.

Стаття надійшла до редколегії 22.10.2015 p.

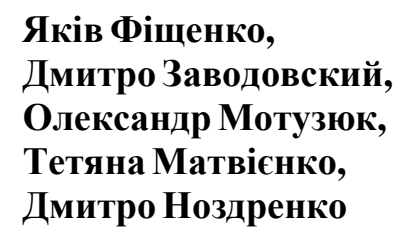

\title{
Вплив дипроспану на розвиток епідурального фіброзу в спинному мозку щура
}

\author{
Київський національний університет імені Тараса Шевченка, ННЦ «Інститут біології»; \\ ДУ «Інститут травматології та ортопедї АМН України»; \\ Східноєвропейський національний університет імені Лесі Украӥнки
}

\begin{abstract}
Препаратами, спроможними зменшувати розвиток післяопераційного епідурального фіброзу, уважають препарати на основі бетаметазону. Досліджено вплив препарату дипроспану в дозі 1 мл/кг на індукований епідуральний фіброз спинного мозку щура. Бетаметазон - основна діюча речовина цього препарату. Показано зниження кількості фіброзних структур при застосуванні дипроспану. При цьому співвідношення сполучної тканини після ініціації фіброзу зменшилася на $27 \%$. Зменшення максимальної товщини фіброзу склало 43 \%, порівняно з контрольними значеннями. Зафіксовано зменшення загальної площі фіброзного утворення - $41 \%$, порівняно 3 контролем. Бетаметазон як діюча речовина в складі препарату дипроспану проявив високу протифіброзну активність і завдяки власній протизапальній дії такий глюкокортикостероїд має, на нашу думку, перспективи для його терапевтичних упроваджень під час лікування епідурального фіброзу спинного мозку.
\end{abstract}

Ключові слова: фіброз, сполучна тканина, дипроспан.

() Фіщенко Я., Заводовский Д., Мотузюк О., Матвієнко Т., Ноздренко Д., 2015 
Постановка наукової проблеми та її значення. Фіброзні захворювання - одна з великих груп патологій, для якої не існує ще ефективних методів терапії, що являє собою велику нерозв'язану проблему для сучасної медицини. Фіброз може вражати найрізноманітніші тканини та органи, такі як печінка, сечовий міхур, оболонки спинного мозку.

Виникнення фіброзу може бути наслідком оперативного втручання, травми, опромінення, інфекції, алергії та ін. факторів. Також не виключають вплив «фіброзного гена»- генетично запрограмованої схильності до розвитку патології [1]. Основним фактором виникнення післяопераційного епідурального фіброзу (ПОЕФ) $є$ хірургічне втручання з приводу остеохондрозу хребта [2]. Фіброзна тканина огортається навколо нервового корінця й починає стискати його та, можливо, судини, що розміщені поряд. Це призводить до больового синдрому, який може з'являтися через декілька тижнів після проведення хірургічного втручання.

Фіброз тканин розглядають як збій у загоєнні ран. Після травми за нормальних умов на місці рани повинна утворитися нова сполучна тканина. Під час цього процесу мезенхімальні фібробласти активуються, починають проліферувати й мігрують у рану, де починають синтезувати у великих кількостях білки матриксу - колаген та фібронектин. Фібробласти, присутні в рані, - міофібробласти синтезують $\alpha$-SMA фактор, який $\epsilon$ обов'язковим для закриття, рубцювання ран $[3,4]$. Імовірно, на певній стадії цього циклу відбувається збій, але сам механізм утворення фіброзу не $є$ ще достатньо вивченим.

Розвиток ПОЕФ у хворих після мікродисектомії (нейрохірургічна операція, спрямована на припинення здавлювання нервового корінця грижею диска) викликає хронічний больовий синдром, заважає післяопераційному відновленню пацієнта та значно знижує результат лікування поперекових гриж [5]. Проблемою є також те, що після оперативних утручань фіброз може розвитися через 3-12 тижнів [6]. Загалом неврологічна картина епідурального фіброзу являє собою ішемічні ураження каудальних відділів спинного мозку [7].

Ортопедичні ж порушення у хворих виражаються помірно або слабо. Часто простежують згладженість поперекового лордозу, обмеження рухливості в попереково-крижовому відділі хребта, зміну постави та ходи. На сьогодні терапевтичні методи лікування включають знеболювальну терапію, застосування засобів, що покращують мікроциркуляцію крові, застосування засобів проти набряку, фізіотерапію й гіперболічну оксигенацію $[8,9]$. Тривалий больовий синдром при епідуральному фіброзі знімається медикаментозними блокадами, які робляться між твердою мозковою оболонкою та внутрішнім краєм міжхребцевого отвору. Протибольова дія епідуральної блокади пов'язана 3 анестезуючими, протизапальними, десенсибілізуючими, протинабряковими ефектами препаратів, що вводяться. Стандартно використовують місцеві анестетики, нерідко в комплексі з глюкокортикоїдами $[10,11,12$.$] .$

Серед найросповсюдженіших синтетичних глюкокортикоїдів, що використовуються в терапії ПОЕФ, є бетаметазон та його похідні. Дія бетаметазону спрямована на пригнічення запалення, алергічної реакції, імуносупрессію та має добре виражену антипроліферативну дію. Широкозастосовуваний препарат на основі бетаметазону - дипроспан. Він має два складники - бетаметазон натрій фосфат та бетаметазону дипропіонат. Перша речовина діє швидко й виводиться за добу. Бетаметазону дипропіонат утворює так зване «депо», тому й діє повільно та виводиться за 10 діб. Бетаметазон впливає на судини, має добре виражений вазоконстрикторний ефект, а також дозозалежний ефект на метаболізм білків, жирів і вуглеводів. Простежено виражений катаболічний вплив на сполучну тканину, жирову, м'язову, кісткову та шкіру [13]. Катаболічний і антипроліферативний ефект дають препарати на основі бетаметазону в якості ефективних терапевтичних засобів при епідуральних фіброзах. Це дало нам змогу перевірити його як профілактичний засіб при епідуральному фіброзі спинного мозку.

Матеріали та методи дослідження. Дослідження проводили на восьми дорослих щурах масою від 0,2 до 0,3 кг, яких поділено на дві групи - контрольну (чотири тварини) та дослідну (чотири тварин). При попередній підготовці до експерименту анестезію здійснювали внутрішньочеревним уведенням нембуталу (40 мг/кг). Фіброз викликали хірургічним методом, шляхом пошкодження твердої мозкової оболонки поперекових відділів хребта наркотизованих щурів, методом розривів волокон межхребцевих дисків. В епідуральну порожнину піддослідних тварин уводили препарат дипроспан у концентраціях 1 мл на 1 кг ваги тварини. Після 10 діб після ініціації фіброзу тварин забивали методом декапітації й виділяли спинний мозок. 
Спинний мозок фіксували протягом двох тижнів у $10 \%$ формаліні, після чого - протягом 10 днів у 7 \% формаліні. Фіксований матеріал промивали під струменем проточної води протягом однієї доби для звільнення від фіксатора. Потім матеріал зневоднювали. Для цього використовували спирти зростаючих концентрацій: $60 \%$ спирт - 6 год, $70 \%$ - 6 год, $80 \%$ - 6 год, $90 \%$ - 4 год, $100 \%$ - 2 год. Зазвичай, матеріал перебував у спирті не менше 24 години, оскільки повне зневоднювання найважливіша умова успішної заливки.

Для приготування зрізів заливали матеріал у парафін-воскову суміш (95 \% парафіну і 5 \% очищеного воску). Перед цим поміщали його в суміш різних частин абсолютного спирту й ксилолу на 1 год. Далі матеріал переносили в ортоксилол на 30-40 хв. Після цього поміщали в насичений розчин парафіну в ортоксилолі при $37^{\circ} \mathrm{C}$ на одну годину, переносили в перший чистий парафін до 2 год при $57^{\circ} \mathrm{C}$, а потім - у другий чистий парафін до 1 год при $57^{\circ} \mathrm{C}$. Заливали матеріал чистим парафіном у формочки 3 паперу, охолоджували у воді й вирізали блок, який наклеювали розплавленим парафіном на дерев' яний кубик.

Різку блоків здійснювали серійно, паралельно та перпендикулярно до ходу м'язових волокон на санному мікротомі (MC-2) товщиною 10 мкм. Виявлення сполучної тканини проводили за класичним методом зафарбовування за Ван-Гізон [14].

Фотографування гістологічних препаратів здійснювали за допомогою цифрової камери SEO на мікроскопі Axioscop фірми «Carl ZEISS». Обробку цифрових фотографій форматів JPEG проводили в програмі Adobe Photoshop 8.0. Фотографії, отримані за допомогою світлової електронної мікроскопії, обробляли за допомогою програми «ВідеоТест Морфологія 5.0» При обробці отриманих цифрових даних використовували методи варіаційної статистики. Достовірність відмінностей між групами визначали за t-критерієм Стьюдента.

Виклад основного матеріалу й обгрунтування отриманих результатів дослідження. Загальновідомо, що після будь-якого хірургічного втручання утворюється рубець як фізіологічна реакція тканин на хірургічне втручання. На жаль, перебіги цього процесу різні й залежать від багатьох причин. Це характерно й для епідурального простору: у низці випадків фіброзна тканина починає посилено формуватися та виникає ситуація, порівнянна з розвитком колоїду.

На 10 добу після індукції епідурального фіброзу товщина прошарку сполучної тканини зросла в 6,5 раза, порівняно з нормою, співвідношення фіброзних структур, таких як максимальна товщина прошарку сполучної тканини та загальна площа фіброзного утворення, дають можливість стверджувати про наявність епідурального фіброзу спинного мозку в піддослідних тварин (рис. 1; 2). Уведення препарату дипроспану в концентраціях 1мл/кг ваги тварини призвели до суттєвих змін у морфофункціональному стані щурів. Співвідношення кількості сполучної після ініціації фіброзу зменшилася на $27 \%$. Зменшення максимальної товщини фіброзу склало, відповідно, $43 \%$, порівняно 3 контролем. Зафіксовано зменшення загальної площі фіброзного утворення - $41 \%$, порівняно 3 контролем (рис. 2). Імовірно, що зміни зачепили внутрішні компоненти жорсткості, які в клітині представлені цитоскелетом, що дало позитивну динаміку розростання сполучної тканини 3 появою рубцевих змін, які виникають, зазвичай, у результаті хронічного запалення.

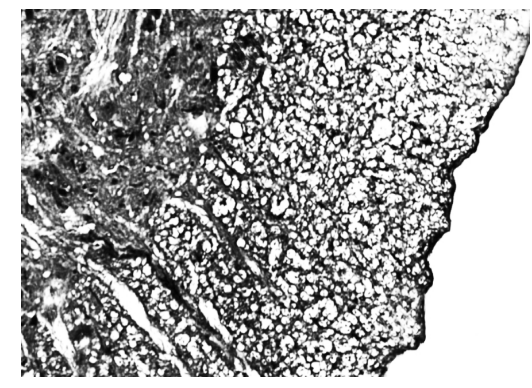

$\boldsymbol{a}$

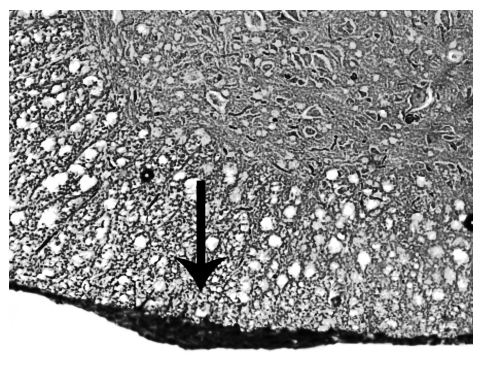

б

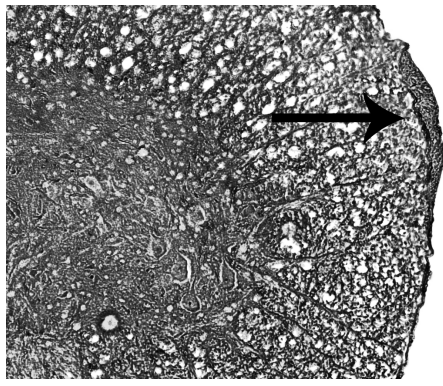

$\boldsymbol{B}$

Рис. 1. Поперечний переріз нативного спинного мозку щура (а), епідуральний фіброз, викликаний методом розривів волокон міжхребцевих дисків (б) та розвиток епідуральногого фіброзу при введені дипроспану в дозі 1мл/кг (в). Світлова мікроскопія, х100. Стрілками показано місия виникнення фіброзних структур 
Відомо, що дипроспан має високу глюкокортикостероїдну та незначну мінералокортикостероїдну активність. Бетаметазон, котрий входить до його складу, чинить сильну протизапальну, протиалергійну й імуносупресивну дію, що, на нашу думку, робить важливий внесок у формування описаних ефектів. Як відомо глюкокортикостероїди розповсюджуються через клітинні мембрани та формують комплекси зі специфічними рецепторами цитоплазми. Ці комплекси потім проникають у клітинне ядро, зв'язуються з ДНК (хроматин) і стимулюють транскрипцію інформаційної РНК і подальший синтез білків різних ензимів. Основні аспекти цих властивостей можуть бути такими: зменшення імуноактивних клітин на рівні осередку запалення, зменшення вазодилатації, стабілізація лізосомальних мембран, пригнічення фагоцитозу, зменшення продукування простагландинів і споріднених сполук. Саме на протизапальних, імунодепресивних та протиалергійних властивостях глюкокортикоїдів може грунтуватись описана терапевтична дія препарату, а зокрема зниження епідуральної рубцевої адгезії в піддослідних щурів та позитивна дія на запобігання епідуральному фіброзу й зменшення щільності фіброзної тканини.

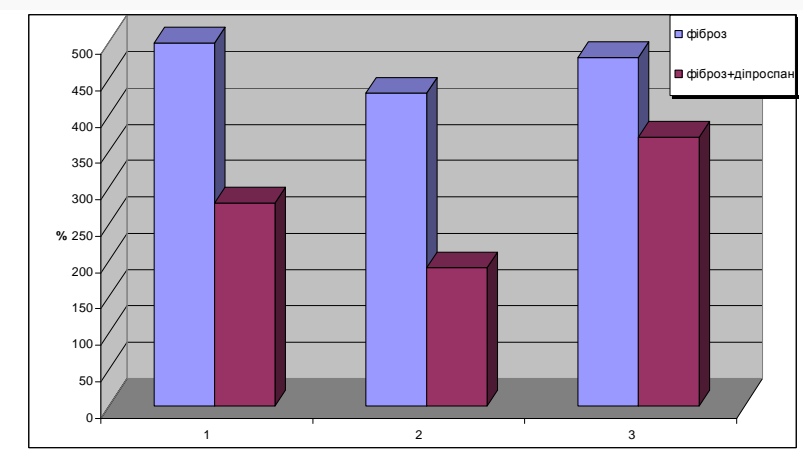

Рис. 2. Співвідношення фіброзних структур при індукованому епідуральному фіброзі та при дії дипроспану в концентрації 1мг/кг, відображені у відсотках від контрольних значень, прийнятих за 100 \%:

1 - кількість сполучної тканини в різні періоди після ініиіації фіброзу, відображено у відсотках від контрольних значень;

2 - максимальна товщина прошарку сполучної тканини після ініщіащії фіброзу, відображено у відсотках від контрольних значень;

3 - загальна площа фіброзного утворення після ініңіащії фіброзу, відображено у відсотках від контрольних значень.

Протизапальний ефект препарату обумовлений, на нашу думку, багатьма чинниками. Одним 3 основних, імовірно, $є$ інгібування фосфоліпази $\mathrm{A}_{2} 3$ подальшим пригнобленням утворення протизапальних медіаторів і лейкотрієнів. Крім того, описана властивість стабілізації препаратом клітинної мембрани [10], у т. ч. мембрани лізосом, запобігає виходу лізосомальних ферментів і знижує їх концентрацію у вогнищі запалення, знижуючи таким чином швидкий ріст епідурального фіброзу. Як відомо, деградація й денатурація колагену відбувається під впливом колагенази, яка є основним ферментом, специфічним для колагену I і III типів. Джерело колагенази - нейтрофільні гранулоцити, моноцити та фібробласти. Гальмування дипроспаном міграції нейтрофілів і макрофагів у вогнище запалення й пригнічення їх фагоцитарної активності [11] зменшує набряки пошкодженої тканини, покращує мікроциркуляцію, зменшує ексудацію рідини та тим самим запобігає стрімкому розвитку епідуральних фіброзних утворювань. Свій внесок, на нашу думку повинна робити й протиалергічна дія препарату, яка розвивається в результаті зниження синтезу й секреції медіаторів алергії, гальмування вивільнення із сенсибілізованих огрядних кліток і базофілів гістаміну та інших біологічно активних речовин, зменшення числа циркулюючих базофілів, придушення проліферації лімфоїдної й сполучної тканин, пригноблення антитілоутворення [10-11]. Виявлений достовірний взаємозв'язок між високим рівнем остеопротегиріну сироватки крові та розвитком післяопераційного епідурального фіброзу [13]. Остеопротегирін - розчинна фракція фактора некрозу пухлини, його зв'язок із розвитком епідуріту на сьогодні вивчений слабо. Дослідники передбачають, що до підвищеної експресії остеопротегиріну можуть приводити цитокини, які беруть участь у процесах загоєння тканин. Тому описані ефекти дії дипроспану можуть бути пов’язані з його протизапальною дією. 
Отже, бетаметазон як діюча речовина в складі препарату дипроспану проявляє високу глюкокортикостероїдну активність і лише мінімальний мінералокортикоїдний ефект. Завдяки протизапальній дії та можливості понизити епідуральну рубцевою адгезію такий комплекс має, на нашу думку, перспективи для його терапевтичних упроваджень при лікуванні епідурального фіброзу спинного мозку.

\section{Джерела та література}

1. Riordan J. R. Identification of the cystic fibrosis gene: cloning and characterization of complementary DNA / J. R. Riordan, J. M. Rommens, B. Kerem [et al.]. - Science, 1989. - 245. - S. 1066-1073.

2. Исаева Н. В. Клинические особенности послеоперационного эпидурального фиброза / Н. В. Исаева, М. Г. Дралюк // Неврологический весник. - 2009. - T. XLI, 4. - С. 55-60.

3. Gabbiani G. The myofibroblast in wound healing and fibrocontractive diseases / G. Gabbiani // J. Pathol. 2000. - S. 500-503.

4. Bedossa P. Liver extracellular matrix in health and disease / P. Bedossa, V. Paradis // J. Pathol. - 2000. S. 504-515.

5. Robertson J. T. Role of peridural fibrosis in the failed back: a review Eur / J. T. Robertson // Spine J. - 1996. Vol. 5. - № 1. - P. 2-6.

6. Ross J. S. The postoperative lumbar spine: evaluation of epidural scar over a 1-year period. / J. S. Ross, N. Obuchowski, R. Zepp // AJNR Am J Neuroradiol. 1998. - S. 183-186.

7. Хайбуллин Р. Г. Хирургическое лечение рецидивирующего пояснично-крестцового / Р. Г. Хайбуллин // Нейрохирургия. - 2007. - № 3. - С.132-133.

8. Шоломов И. И. Консервативное ведение больных с болезнью оперированного диска / И. И. Шоломов, О. В. Бейдик, Т. В. Гришина // Невролог. вестик. - 2005. - Т. 18, № 6. - С. 47-56.

9. Hansson P. T. Pharmacological treatment of peripheral neuropathic pain conditions based on shared commonalities despite multiple etiologies: topical review / P. T. Hansson, A. H. Dickenson // Pain. Vol. 113, № 3. - P. 251-254.

10. Robertson J. T. Role of peridural fibrosis in the failed back: a review Eur / J. T. Robertson // Spine J. 1996. Vol. 5, № 1. - P. 2-6.

11. Papagelopoulos P. J. Treatment of lumbosacral radicular pain with epidural steroid injections / P. J. Papagelopoulos, H. G. Petrou, Triantafyllidis P. G. [et al.] // Orhtopedics. - 2001. - Vol. 24, № 2. - P. 145-149

12. Benzon H. T. Epidural steroid injectoins for low back pain and lumbosacral radiculopathy / H. T. Benzon. Pain. - 1986. - Vol. 24, № 3. - P. 277-295.

13. Menendez M. I. Pharmacokinetics of intra-articular betamethasone sodium phosphate and betamethasone acetate and endogenous hydrocortisone suppression in exercising horses / M. I. Menendez, M. A. Phelps, A. L. Bertone // J Vet Pharmacol Ther. - 2016. - 39. P. 22-26.

14. Коржевский Д. Э. Краткое изложение основ гистологической техники для врачей и лаборантовгистологов / Д. Э. Коржевский. - СПб., 2005. - 47 с.

Фищенко Яков, Заводовский Дмитрий, Мотузюк Александр, Матвиенко Татьяна, Ноздренко Дмитрий. Влияние дипроспана на развитие эпидурального фиброза в спинном мозга крыс. В качестве препаратов, способных уменьшать развитие послеоперационного эпидурального фиброза, зарекомендовали себя препараты на основе бетаметазона. Проведено исследование влияния препарата дипроспан в дозе 1 мл/кг на индуцированный эпидуральный фиброз спинного мозга крысы. Бетаметазон является основным действующим веществом данного препарата. Показано снижение количества фиброзных структур при применении дипроспана. При этом соотношение соединительной ткани после инициации фиброза уменьшилась на $27 \%$. Уменьшение максимальной толщины фиброза составило $43 \%$, по сравнению с контрольными значениями. Зафиксировано уменьшение общей площади фиброзного образования на $41 \%$, по сравнению с контролем. Бетаметазон как действующее вещество в составе препарата дипроспана проявляет высокую противофиброзную активность и, благодаря собственному противовоспалительному действию, такой глюкокортикостероид имеет, по нашему мнению, перспективы для его терапевтических внедрений при лечении эпидурального фиброза спинного мозга.

Ключевые слова: фиброз, соединительная ткань, дипроспан.

Fishenenko Yakiv, Zavodovskyi Dmytro, Мотузюк Oleksandr, Matvienko Tetiayna, Nozdrenko Dmytro. Diprospan Impact on Development of Epidural Fibrosis in Rat Spinal Cord. As agent potent to reduce post operational epidural fibrosis betamethasone based drags proved to be useful. Investigation of the diprospan in dose 1 $\mathrm{ml} / \mathrm{kg}$ impact on artificially induced epidural fibrosis of rat spinal cord was conducted. Betamethason is main active component of this drug. Reduce of the number of fibrosis structures after diprospan application was shown. Wherein fraction of connective tissue reduced on $27 \%$. Decline of maximum thickness reached $43 \%$ relative to control. Area 
reduction of fibrosis was observed. It was lesser up to $41 \%$ relative to control. Betamethasone as active component through its anti-inflammatory effect as a glucocorticosteroid has high potential for therapy of epidural spinal cord fibrosis. Also betamethason included in diprospan drag formula has high glucocorticosteroid effect but mineralcorticoidal effect is relatively insignificant. Through antiinflamatory action and ability greatly reduce epidural scar adhesion this drug mixture can by useful in medical practice related to spinal cord fibrosis.

Key words: fibrosis, connective tissue, diprospan.

Стаття надійшла до редколегії 20.11.2015 p. 